\title{
Accrual-Based and Real Earnings Management Activities around Seasoned Equity Offerings
}

\author{
Daniel A. Cohen and Paul Zarowin* \\ New York University \\ Stern School of Business
}

January, 2008

\begin{abstract}
We examine earnings management behavior around SEOs, focusing on both real activities and accrual-based manipulation, and how this behavior varies over time and cross-sectionally. Although research has addressed the issues of earnings management around SEOs and earnings management via real activities manipulation, ours is the first paper to put these two issues together. We make three contributions to the literature. First, we document that firms use real, as well as accrual-based, earnings management tools around SEOs. Second, consistent with the expectation that the Sarbanes-Oxley Act (SOX) has made accrual-based earnings management more costly, we find that firms have substituted from accrual to real earnings management after SOX. Finally, we show how the tendency for firms to tradeoff real versus accrual-based earnings management activities around SEOs varies cross-sectionally. We find that firms' choices vary predictably as a function of the firm's ability to use accrual management and the costs of doing so. Our model is a first step in examining how firms tradeoff between real versus accrual methods of earnings management.
\end{abstract}

\footnotetext{
*Contact information: Daniel can be reached atdcohen@stern.nyu.edu, 212-998-0267 and Paul can be reached at pzarowin@stern.nyu.edu, 212-998-0015. We thank the Stern School of Business at New York University for financial support.
} 


\title{
Accrual-Based and Real Earnings Management Activities around Seasoned Equity Offerings
}

\begin{abstract}
We examine earnings management behavior around SEOs, focusing on both real activities and accrual-based manipulation, and how this behavior varies over time and cross-sectionally. Although research has addressed the issues of earnings management around SEOs and earnings management via real activities manipulation, ours is the first paper to put these two issues together. We make three contributions to the literature. First, we document that firms use real, as well as accrual-based, earnings management tools around SEOs. Second, consistent with the expectation that the Sarbanes-Oxley Act (SOX) has made accrual-based earnings management more costly, we find that firms have substituted from accrual to real earnings management after SOX. Finally, we show how the tendency for firms to tradeoff real versus accrual-based earnings management activities around SEO's varies cross-sectionally. We find that firms' choices vary predictably as a function of the firm's ability to use accrual management and the costs of doing so. Our model is a first step in examining how firms tradeoff between real versus accrual methods of earnings management.
\end{abstract}




\section{Introduction}

In this paper, we examine both real and accrual-based earnings management activities around seasoned equity offerings (SEOs). While a number of papers have documented evidence in support of income-increasing earnings management activities around SEOs (e.g., Rangan 1998, Teoh et al. 1998, Shivakumar 2000, and DuCharme et al. 2000) they have studied accrual-based manipulation exclusively. Such accruals-based earnings management activities have no direct cash flows consequences. Our research objective is important, since firms might use multiple strategies to manage their reported earnings around SEOs, for example, through real activities manipulations that does affect cash flows. We refer to real activities manipulation as actions managers take that deviate from normal business practices. ${ }^{1}$

Recently, there has been an increased appreciation for understanding and documenting how firms manage earnings thru real activities manipulation in addition to accrual-based activities (e.g., Gunny 2006, Roychowdhury 2006, and Zang 2006). For example, Roychowdhury (2006) finds evidence that firms use multiple real earnings management tools in order to meet certain financial reporting benchmarks to avoid reporting annual losses. In particular, his evidence suggests that managers are providing price discounts to temporarily boost sales, reducing discretionary expenditures in order to improve reported margins, and overproducing to lower the cost of goods sold.

In a recent survey of top executives, Graham et al. (2005) provide evidence suggesting that managers prefer real earnings management activities compared to

\footnotetext{
${ }^{1}$ This definition is consistent with Roychowdhury (2006) who defines real activities manipulations as: "...management actions that deviate from normal business practices, undertaken with the primary objective of meeting certain earnings thresholds."
} 
accrual-based earnings management. This is the case since real management activities can be indistinguishable from optimal business decisions, and thus more difficult to detect, although the costs involved in such activities can be economically significant to the firm. Moreover, consistent with the conjectures made by Graham et al. (2005), Cohen et al. (2007) find that mangers have shifted away from accrual to real earnings management in the post Sarbanes-Oxley Act (SOX) period. This evidence implies that in the post-SOX period that followed highly publicized accounting scandals, the need to avoid detection of accrual-based earnings management is greater than in previous periods inducing managers to shift from accrual-based to real earnings management activities.

Despite the increasing interest in and importance of real earnings management activities, no study to date has examined whether and how firms engage in real earnings management around SEOs, and how real and accrual-based earnings management interact around these important corporate events. We fill this gap in the literature.

To capture accrual-based earnings management we use the modified crosssectional Jones model (Jones 1991) as described in Dechow et al. (1995). To capture real earnings management, we follow Roychowdhury (2006) and estimate abnormal levels of cash flows from operations, discretionary expenses (advertising, R\&D, and SG\&A), and production costs. In addition, we combine these three measures into a comprehensive aggregate measure of real earnings management.

Consistent with prior studies (e.g., Teoh et al. 1998, Rangan 1998, among others) we find that firms use accrual-based earnings management around SEOs. In addition, also consistent with previous research, we find that SEO firms tend to both outperform their 
industry peers in the period preceding the SEO and underperform their peers following the SEO, as evidenced by their returns on assets (ROA).

We make three contributions to the literature. First, consistent with the evidence in Zhang (2006) that firms use multiple earnings management tools, we document that firms use real, as well as accrual-based, earnings management activities around SEOs. Second, we show how firms' use of real versus accrual earnings management around SEOs has varied inter-temporally, by comparing the relative amounts of each type before and after the passage of the recent SOX regulation. Consistent with the expectation that SOX has made accrual earnings management more costly, we find a shift from accrualbased to real earnings management after SOX.

Finally, we show how the tendency for firms to tradeoff real versus accrual earnings management around SEOs varies cross-sectionally. We estimate a two-stage model using the Heckman (1979) method to control for firms' self-selection to manage reported earnings. In the first stage, we estimate a parsimonious selection model to explain firms' overall decisions to engage in earnings management or not. Next, conditional on this first stage analysis, in the second stage we analyze the factors determining the preference for real earnings management strategies as compared to accruals based ones.

We empirically model a firm's choice to use real and/or accrual earnings management tools around SEOs as a function of its ability to use accrual management and the costs of doing so. We represent a firm's ability to manage earnings through accruals by its net operating assets (NOA) position (following Barton and Simko 2002), and the costs of such behavior proxied by its auditor characteristics, analyst following, 
and litigation probability. We find that firms' choices vary predictably with these factors. Although we use our model to study SEOs, we emphasize that the model could be used more generally to study how firms tradeoff between the two methods of earnings management, an important topic for future research.

The rest of the paper is organized as follows. Section 2 reviews related literatures on earnings management around SEOs, real earnings management, and the effect of SOX on earnings management. Section 3 discusses our empirical methodology, including our sample construction and estimation equations. Section 4 discusses our empirical results. Section 5 concludes.

\section{Related Literature and Research Objectives}

Our paper unites two streams of research that have previously been disparate, one on real earnings management and the other on earnings management around SEOs. ${ }^{2} \mathrm{We}$ first discuss related research, and then we build on the existing body of evidence to state our research objectives.

\subsection{Accrual-based Earnings Management around SEOs}

Beginning with Rangan (1998) and Teoh et al. (1998), researchers have been concerned with whether firms manage reported earnings during SEOs, and the accounting and stock market consequences associated with such activities. This literature has been motivated by the empirical findings that SEOs are followed by both poor stock returns

\footnotetext{
2 Earnings management around SEOs is really part of a larger literature studying earnings management around corporate events such as IPOs, management buyouts, stock repurchases, and stock for stock acquisitions.
} 
and poor earnings performance, leading researchers to suspect that earnings have been managed upward in anticipation of the SEO, and subsequently reverse (e.g., Teoh et al. 1998, Rangan 1998, and Shivakumar 2000).

Rangan (1998) finds positive abnormal accruals (i.e., upwardly managed reported earnings) on average for SEO firms during the year around the SEO, and that these accruals predict both earnings reversals and poor stock performance in the following year. He interprets his findings to mean that firms manage earnings upward around SEOs, and that the stock market is mislead by the upwardly managed earnings, temporarily overvaluing issuing firms and then being disappointed by their predictable earnings declines, which cause their stock prices to subsequently fall. Teoh et al. (1998) report similar evidence to Rangan, with the additional finding that SEO issuers who upwardly manage earnings more (greater positive abnormal accruals) have lower post-event stock returns and subsequent earnings. Their interpretation is the same as the one offered by Rangan (1998).

Shivakumar (2000) also finds evidence consistent with accruals earnings management around SEOs, but in contrast to Rangan and Teoh et al., he shows that the stock market does not react inefficiently to the upwardly managed earnings, but that investors rationally undo these effects. He attributes Rangan's and Teoh et al.'s findings of abnormal stock returns to test misspecification, arguing that the earnings management is not designed to fool or mislead investors, but is itself a rational response to the market's anticipation that firms will upwardly manage earnings around the SEO.

DuCharme et al. (2004) add a legal dimension to the research on SEOs. They show that abnormal accruals are highest for SEOs that are subsequently sued, and 
settlement amounts are also positively related to the levels of abnormal accruals. Likewise, post-SEO earnings reversals are more pronounced and post-SEO stock returns are lower for litigated SEOs. They interpret their results as indicating that the earnings manipulation drives the post-SEO litigation. Collectively, these papers find strong evidence of accruals earnings management around SEOs, and link the earnings management activities to post event litigation. There is disagreement, however, as to whether the stock market is indeed misled by the earnings management activities around SEOs.

\subsection{Real Earnings Management}

Although real earnings management has not been as widely studied as accrualbased earnings management, Graham et al.'s (2005) survey finds that managers prefer real activities manipulation, by such means as reducing discretionary expenditures or capital investments, over accruals manipulation as a way to manage earnings. These real earnings management activities are significantly different than accrual-based ones as they have direct cash flows effects. Graham et al. (2005, p. 32) find

.....strong evidence that managers take real economic actions to maintain accounting appearances. In particular, $80 \%$ of survey participants report that they would decrease discretionary spending on $R \& D$, advertising, and maintenance to meet an earnings target. More than half (55.3\%) state that they would delay starting a new project to meet an earnings target, even if such a delay entailed a small sacrifice in value. . .

There are at least two reasons for executives' greater willingness to manage earnings through real activities than through accruals. First, accrual-based earnings management is more likely to draw auditor or regulatory scrutiny than real decisions, 
such as those related to product pricing, production, and expenditures on research and development or advertising. Second, relying on accrual manipulation alone is risky. The realized shortfall between unmanaged earnings and the desired threshold can exceed the amount by which it is possible to manipulate accruals after the end of the fiscal period. If reported income falls below the threshold and all accrual-based strategies to meet it are exhausted, managers are left with no options because real activities cannot be adjusted at or after the end of the fiscal reporting period.

Consistent with these predictions, researchers have documented variations in R\&D expenditures and asset sales linked to firms meeting and/or beating earnings benchmarks. For example, Bartov (1993) finds that firms with negative earnings changes report higher profits from asset sales, suggesting that the profits are used to blunt the bad earnings news. Dechow and Sloan (1991) find that executives near the end of their tenure reduce $R \& D$ expenditures to increase short-term earnings. In related studies, Baber et al. (1991) and Bushee (1998) report evidence consistent with firms reducing R\&D expenditures to meet earnings benchmarks such as positive earnings or positive earnings changes.

Recently, three related studies examine real earnings management activities and their capital market consequences. Roychowdhury (2006) focuses on real activities manipulations, which he defines as management actions that deviate from normal business practices, undertaken with the primary objective to mislead certain stakeholders into believing that earnings benchmarks have been met in the normal course of operations. Focusing on the zero earnings threshold and examining annual data, he finds evidence consistent with firms trying to avoid reporting losses in three ways: (1) boosting 
sales through accelerating their timing and/or generating additional unsustainable sales through increased price discounts or more lenient credit terms; (2) overproducing and thereby allocating more overhead to inventory and less to cost of goods sold, which leads to lower cost of goods sold and increased operating margins; or (3) aggressively reducing aggregate discretionary expenses (defined as the sum of research and development, advertising, and SG\&A expenses) to improve margins. This is most likely to occur when such discretionary expenses do not generate immediate revenues and income.

Zang (2006) analyzes the tradeoffs between accrual manipulations and real earnings management. She suggests that decisions to manage earnings through "real" actions precede decisions to manage earnings through accruals. Her results show that real manipulation is positively correlated with the costs of accrual manipulation, and that accrual and real manipulations are negatively correlated. These findings lead her to conclude that managers treat the two strategies as substitutes.

In related research, Gunny (2005) examines the consequences of real earnings management and finds that real earnings management has a significant negative impact on future operating performance. Additionally, it appears that capital markets participants mostly recognize the future earnings implications of managers' myopic behaviors.

\subsection{Real Earnings Management in the Post-SOX period}

Recent research has focused on evaluating and understanding the economic consequences of the Sarbanes-Oxley Act (SOX), arguably "the most far-reaching reforms of American business practices since the time of Franklin D. Roosevelt." ${ }^{3}$ One of the

\footnotetext{
${ }^{3}$ Elizabeth Bumiller, "Bush Signs Bill Aimed at Fraud in Corporations," New York Times, July 31, 2002.
} 
interesting issues that have been addressed in the literature is whether earnings management overall and the mix of strategies (i.e., accrual-based versus real activities) have changed significantly in the post-SOX period. In particular, as Graham, et al. (2005, p.36) conjecture:

... the aftermath of accounting scandals at Enron and WorldCom and the certification requirements imposed by the Sarbanes-Oxley Act may have changed managers' preferences for the mix between taking accounting versus real actions to manage earnings.

Analyzing trends in earnings management practices in the pre- and post-SOX periods, Cohen et al. (2007) find that firms switched from accrual-based to real earnings management methods after the passage of SOX. They report that firms that just achieved important earnings benchmarks used fewer accruals and more real earnings management strategies after SOX when compared to similar firms before SOX.

The apparent change in managerial behavior with respect to the alternative strategies employed to manage reported earnings after SOX motivates us to examine whether any such change can be observed for firms that are engaging in seasoned equity offerings. Specifically, we seek to understand whether firms engaging in SEOs in the post-SOX period use different earnings management tools as compared to the pre-SOX period. The SOX regulation is a natural setting to perform this type of an experiment, as it is regarded as an exogenous shock affecting all the firms in the US economy.

In summary, there is strong evidence of real earnings management activities, achieved via multiple means, and it is likely linked to meeting certain earnings benchmarks. Building on the above, we first seek to examine whether real earnings management activities are used as earnings management tools around SEOs and whether there exists any substitution or complementary relation with accrual-based strategies. In 
line with the literature to date, we also examine the subsequent performance following SEOs as a function of the earnings management vehicle used around the year of the SEO. Our second objective is to investigate whether SEO firms' choice of earnings management tools has changed from the pre-SOX to the post-SOX period. Finally, we examine the cross-sectional determinants of the choices firms make among different earnings management activities around SEOs, to better understand why certain firms will choose different earnings management tools around the year of the SEO.

Next, we discuss the empirical methodology we employ to address our research objectives.

\section{Empirical Methodology}

\subsection{Data and Sample Description}

Our SEO sample consists of 1,511 completed U.S. offers over the 1987 to 2006 period, and is obtained from the Securities Data Company (SDC) New Issue database. The sample criteria requires SEOs to be issues of common stocks by U.S. issuers which are listed on NYSE, NASDAQ, or AMEX and exclude the following: (1) SEOs lacking COMPUSTAT annual financial statement data for the 4 years prior to the SEO filing date, the offer year and the subsequent year, (2) completed SEOs with offer prices less than $\$ 5$ and withdrawn SEOs with filing range midpoint less than $\$ 5$, (3) spin-offs, (4) reverse LBOs, (5) closed-end fund, unit investment trusts, REITS and limited partnerships, (6) rights and standby issues, (7) simultaneous or combined offers of several classes of securities such as unit offers of stocks and warrants and, (8) non-domestic and simultaneous domestic-international offers. 
We collect our financial data from the COMPUSTAT annual industrial and research files for the sample period. We restrict our sample to all nonfinancial firms with available data, and require at least 8 observations in each 2-digit SIC grouping per year. Further, we require that each firm-year observation has the data necessary to calculate the discretionary accruals metrics and real earnings management proxies we employ in our analysis. This restriction (which we share with other papers on SEOs) likely introduces a survivorship bias into the sample resulting in the inclusion of larger and more successful firms. We expect that this will reduce the variation in our earnings management metrics resulting in a more conservative test of our research questions.

Following Collins and Hribar (2002), we use cash flows from operations obtained from the Statement of Cash Flows reported under the Statement of Financial Accounting Standards No. 95 (SFAS No. 95, FASB 1987). ${ }^{4}$ The sample period of 1987-2006 permits us to use SFAS No. 95 statement of cash flow data to estimate accruals, rather than a balance sheet approach.

Table 1 reports descriptive statistics of our SEO sample. Panel A provides summary information on the size and offering characteristics. Consistent with previous studies (e.g., Teoh et al. 1998, Rangan, 1998), our sample of SEO firms tends to have high bookto-market ratios, averaging around 2.5. This is not surprising, since firms tend to issue equity when valuations are high. Average offer size is about $1 / 4$ of pre-offer market value.

Panel B shows the distribution of SEOs over time. Also, consistent with previous research, there is some time clustering, as many SEOs occurred during the 1990's. For example, during 1991-1999, there were 879 out our total sample of 1,511 SEOs (58\%).

${ }^{4}$ SFAS No. 95 requires firms to present a statement of cash flows for fiscal years ending after July 15, 1988. Some firms early-adopted SFAS No. 95, so our sample begins in 1987. 
This is also not surprising, since the stock market boomed during this period, and equity valuations were high. Since the market experienced a significant downturn beginning in 2000, there have been fewer SEOs.

Panel C reports the frequency of SEOs by industry and indicates that while SEOs occur in many different types of businesses, during our sample period they were especially frequent in high technology areas as chemical products, computer equipment, electronic equipment, and electronic services. Together, these four industries comprise more than $40 \%$ of the sample Again, this finding is not surprising, as the high tech fields led the 1990s stock market boom. In summary, our sample exhibits similar characteristics to samples in previous SEO research, indicating that SEOs are clustered both in time and by industries.

\subsection{Earnings Management Metrics}

\section{Accrual-based Earnings Management}

We use a cross-sectional model of discretionary accruals, where for each year we estimate the model for every industry classified by its 2-digit SIC code. Thus, our approach partially controls for industry-wide changes in economic conditions that affect total accruals while allowing the coefficients to vary across time (Kasznik, 1999; DeFond and Jiambalvo, 1994). ${ }^{5}$

Our primary model is the modified cross-sectional Jones model (Jones 1991) as described in Dechow et al. (1995). The modified Jones model is estimated for each 2 digit SIC-year grouping as follows:

\footnotetext{
${ }^{5}$ We obtain qualitatively the same results when we use a time-series approach which assumes temporal stationarity of the parameters for each firm.
} 


$$
\frac{T A_{i t}}{\text { Assets }_{i, t-1}}=k_{1 t} \frac{1}{\text { Assets }_{i, t-1}}+k_{2} \frac{\Delta \operatorname{Re} v_{i t}}{\text { Assets }_{i, t-1}}+k_{3} \frac{P P E_{i t}}{\operatorname{Assets}_{i, t-1}}+\varepsilon_{i t}
$$

where, for fiscal year $t$ and firm $i, T A$ represents total accruals defined as:

$T A_{i t}=E B X I_{i t}-C F O_{i t}$, where $E B X I$ is the earnings before extraordinary items and discontinued operations (annual Compustat data item 123) and $C F O$ is the operating cash flows (from continuing operations) taken from the statement of cash flows (annual Compustat data item 308 - annual Compustat data item 124), Asset it- $_{\text {represents total }}$ assets (annual Compustat data item 6), $\triangle R E V_{i t}$ is the change in revenues (annual Compustat data item 12) from the preceding year and $P P E_{i t}$ is the gross value of property, plant and equipment (annual Compustat data item 7).

The coefficient estimates from equation (1) are used to estimate the firm-specific normal accruals (NA it) for our sample firms:

$$
N A_{i t}=\hat{k}_{1 t} \frac{1}{\operatorname{Assets}_{i, t-1}}+\hat{k}_{2} \frac{\left(\Delta \operatorname{Re} v_{i t}-\Delta A R_{i t}\right)}{\operatorname{Assets}_{i, t-1}}+\hat{k}_{3} \frac{P P E_{i t}}{\operatorname{Assets}_{i, t-1}}
$$

where $\triangle A R_{i t}$ is the change in accounts receivable (annual Compustat data item 2) from the preceding year. Following the methodology used in the literature, we estimate the industry-specific regressions using the change in reported revenues, implicitly assuming no discretionary choices with respect to revenue recognition. However, while computing the normal accruals, we adjust the reported revenues of the sample firms for the change in accounts receivable to capture any potential accounting discretion arising from credit sales. Our measure of discretionary accruals is the difference between total accruals and the fitted normal accruals, defined as $D A_{i t}=\left(T A_{i t} / A_{\text {sset }}\right.$ it- $)-N A_{i t}$. 
In our robustness tests, we used two alternative measures of discretionary accruals. In one alternative measure we estimated the following in the first stage:

$$
\frac{T A_{i t}}{\text { Assets }_{i, t-1}}=k_{1 t} \frac{1}{\operatorname{Assets}_{i, t-1}}+k_{2} \frac{\left(\Delta R E V_{i t}-\Delta A R_{i t}\right)}{\operatorname{Assets}_{i, t-1}}+k_{3} \frac{P P E_{i t}}{\operatorname{Assets}_{i, t-1}}+\varepsilon_{i t}
$$

Using the coefficient estimates obtained from (3), we calculated the level of normal accruals $\left(N A_{i t}\right)$ as a percent of lagged total assets. We also repeat our tests by using a measure based on the performance-matched discretionary accruals advanced in Kothari Leone, and Wasley (2005). As suggested by Kothari et al. (2005), we match each firmyear observation with another from the same two-digit SIC code and year with the closest return on assets in the current year, $R O A$ it (net income divided by total assets). ${ }^{6}$ Based on the previous papers on SEOs and accrual earnings management cited above, we predict that our sample will have positive abnormal accruals around the SEO event.

\section{Real Earnings Management}

We rely on prior studies to develop our proxies for real earnings management. As in Roychowdhury (2006), we consider three metrics: the abnormal levels of cash flow from operations (CFO), discretionary expenses, and production costs to study the level of real activities manipulations. Subsequent studies, such as Zang (2006) and Gunny (2006), provide evidence of the construct validity of these proxies. We focus on three manipulation methods and their impact on the above three variables:

\footnotetext{
${ }^{6} \mathrm{We}$ also carry out performance matching based on two-digit SIC code, year and ROA (both current ROA and lagged ROA) and obtain results similar to those reported in the paper. Our results using these alternate measures of accruals are consistent with those reported in the paper.
} 
1. Acceleration of the timing of sales through increased price discounts or more lenient credit terms. Such discounts and lenient credit terms will temporarily increase sales volumes, but these are likely to disappear once the firm reverts to old prices. The additional sales will boost current period earnings, assuming the margins are positive. However, both price discounts and more lenient credit terms will result in lower cash flows in the current period.

2. Reporting of lower cost of goods sold through increased production. Managers can increase production more than necessary in order to increase earnings. When managers produce more units, they can spread the fixed overhead costs over a larger number of units, thus lowering fixed costs per unit. As long as the reduction in fixed costs per unit is not offset by any increase in marginal cost per unit, total cost per unit declines. This decreases reported COGS and the firm can report higher operating margins. However, the firm will still incur other production and holding costs that will lead to higher annual production costs relative to sales, and lower cash flows from operations given sales levels.

3. Decreases in discretionary expenses which include advertising expense, research and development, and SG\&A expenses. Reducing such expenses will boost current period earnings. It could also lead to higher current period cash flows (at the risk of lower future cash flows) if the firm generally paid for such expenses in cash. 
We first generate the normal levels of CFO, discretionary expenses and production costs using the model developed by Dechow, Kothari and Watts (1998) as implemented in Roychowdhury (2006). We express normal CFO as a linear function of sales and change in sales. To estimate this model, we run the following cross-sectional regression for each industry and year:

$$
\frac{\text { CFO }_{i t}}{\text { Assets }_{i, t-1}}=k_{1 t} \frac{1}{\text { Assets }_{i, t-1}}+k_{2} \frac{\text { Sales }_{i t}}{\text { Assets }_{i, t-1}}+k_{3} \frac{\Delta \text { Sale }_{i t}}{\text { Assets }_{i, t-1}}+\varepsilon_{i t}
$$

Abnormal CFO is actual CFO minus the normal level of CFO calculated using the estimated coefficients from (4).

Production costs are defined as the sum of cost of goods sold (COGS) and change in inventory during the year. We model COGS as a linear function of contemporaneous sales:

$$
\frac{\operatorname{COGS}_{i t}}{\operatorname{Assets}_{i, t-1}}=k_{1 t} \frac{1}{\operatorname{Assets}_{i, t-1}}+k_{2} \frac{\text { Sales }_{i t}}{\operatorname{Assets}_{i, t-1}}+\varepsilon_{i t}
$$

Next, we model inventory growth as a linear function of the contemporaneous and lagged change in sales:

$$
\frac{\Delta I N V_{i t}}{\text { Assets }_{i, t-1}}=k_{1 t} \frac{1}{\text { Assets }_{i, t-1}}+k_{2} \frac{\Delta \text { Sales }_{i t}}{\text { Assets }_{i, t-1}}+k_{3} \frac{\Delta \text { Sales }_{i, t-1}}{\text { Assets }_{i, t-1}}+\varepsilon_{i t}
$$

Using (5) and (6), we estimate the normal level of production costs as:

$$
\frac{\operatorname{Prod}_{i t}}{\text { Assets }_{i, t-1}}=k_{1 t} \frac{1}{\text { Assets }_{i, t-1}}+k_{2} \frac{\text { Sales }_{i t}}{\text { Assets }_{i, t-1}}+k_{3} \frac{\Delta \text { Sales }_{i t}}{\text { Assets }_{i, t-1}}+k_{4} \frac{\Delta \text { Sales }_{i t-1}}{\text { Assets }_{i, t-1}}+\varepsilon_{i t}
$$

The normal level of discretionary expenses can be expressed as a linear function of sales: 


$$
\frac{\operatorname{DiscExp}_{i t}}{\operatorname{Assets}_{i, t-1}}=k_{1 t} \frac{1}{\operatorname{Assets}_{i, t-1}}+k_{2} \frac{\text { Sales }_{i t}}{\operatorname{Assets}_{i, t-1}}+\varepsilon_{i t}
$$

Modeling discretionary expenses as a function of current sales creates a mechanical problem if firms manage sales upwards to increase reported earnings in a certain year, resulting in significantly lower residuals from running a regression as specified in (8). To address this issue, we model discretionary expenses as a function of lagged sales and estimate the following model to derive 'normal' levels of discretionary expenses:

$$
\frac{\operatorname{DiscExp}_{i t}}{\operatorname{Assets}_{i, t-1}}=k_{1 t} \frac{1}{\operatorname{Assets}_{i, t-1}}+k_{2} \frac{\text { Sales }_{i, t-1}}{\operatorname{Assets}_{i, t-1}}+\varepsilon_{i t}
$$

In the above equations $C F O$ is cash flow from operations in period $t$ (Compustat data item 308 - annual Compustat data item 124); Prod represents the production costs in period $t$, defined as the sum of COGS (annual Compustat data item 41) and the change in inventories (annual Compustat data item 3); DiscExp represents the discretionary expenditures in period $t$, defined as the sum of advertising expenses (annual Compustat data item 45), R\&D expenses (annual Compustat data item 46) ${ }^{7}$ and SG\&A (annual Compustat data item 189). The abnormal CFO (R_CFO), abnormal production costs $\left(R_{-} P R O D\right)$ and abnormal discretionary expenses $\left(R_{-} D I S X\right)$ are computed as the difference between the actual values and the normal levels predicted from equations (4) (7) and (9). We use these three variables as proxies for real earnings management. Given sales levels, firms that manage earnings upwards are likely to have one or all of these: unusually low cash flow from operations, and/or unusually low discretionary expenses, and/or unusually high production costs.

\footnotetext{
${ }^{7}$ As long as SG\&A is available, advertising expenses and R\&D are set to zero if they are missing.
} 
In order to capture the effects of real earnings management through all these three variables in a comprehensive measure, we compute a single variable by combining the three individual real earnings management variables. Specifically, consistent with Zang (2006), we multiply $R_{-} C F O$ and $R \_D I S X$ by negative one so the higher the amount of $R_{-} C F O$ and $R_{-} D I S X$, the more likely it is that the firm is engaging in sales manipulations through price discounts and cutting discretionary expenses. We do not multiply $R_{-} P R O D$ by negative one since higher production costs, as noted earlier, is indicative of overproduction to reduce cost of goods sold. Our combined measure, $R M_{-} P R O X Y$ is the sum of the above standardized variables, $R_{-} C F O, R_{-} P R O D$ and $R_{-} D I S X$. However, we acknowledge that the three individual variables underlying $R M_{-} P R O X Y$ have different implications for earnings which may dilute any results using $R M_{-} P R O X Y$ alone. We thus report results corresponding to the single real earnings management proxy $\left(R M_{-} P R O X Y\right)$ as well as the three individual real earnings management proxies $\left(R_{-} C F O, R_{-} P R O D\right.$ and $\left.R_{-} D I S X\right)$.

\section{Empirical results}

\subsection{Overall Sample}

Table 2 presents median discretionary accruals, abnormal cash flows from operations, abnormal production costs, and abnormal discretionary expenditures, all scaled by beginning of the period total assets, for years -3 to +3 relative to the year of the SEO. We report medians as they are less likely to be influenced by extreme observations.

Consistent with Rangan (1998), Teoh et al. (1998), Shivakumar (2000), and DuCharme et al (2004), we find significant positive abnormal accruals in the year of the 
SEO. Thus, our sample exhibits the same earnings enhancing accruals management as previous papers.

Most important, we find significant positive abnormal production costs, negative abnormal discretionary expenses, and (negative) abnormal CFO in the SEO year, as predicted. This is the first evidence of real earnings management around SEOs.

Interestingly, we find some evidence of negative abnormal production costs and positive abnormal discretionary expenses in the years immediately preceding and immediately following the SEO, although the magnitudes are smaller than in the SEO year, and not necessarily significant. The direction, however, is opposite to what occurs in the SEO year, and suggests that management may adjust production and expenditures in anticipation of, and in response to, the SEO so that over the "long run" abnormal real behavior is minimized.

Table 3 reports the correlations between the various proxies of earnings management in the year of the SEO. The correlation between discretionary accruals and abnormal cash flow from operations is significantly negative (-25\%, Pearson and $-23 \%$, Spearman). This correlation can be explained by (a) firms engaging in accrual-based earnings management and real activities manipulations at the same time, and (b) some manipulation strategies, for instance overproduction, have a positive effect on discretionary accruals and at the same time a negative effect on abnormal cash flows from operations. Consistent with the above interpretation, the correlation coefficient between discretionary accruals and abnormal production costs is significantly positive (3\% Pearson and Spearman) whereas the correlation coefficient between discretionary accruals and discretionary expenses is significantly negative $(-18 \%$, Pearson and $-15 \%$ 
Spearman). Analyzing the correlations among the real activities proxies reveals that the correlation coefficient between abnormal production costs and abnormal discretionary expenses is significantly negative (-28\%, Pearson and $-20 \%$ Spearman). This implies that managers are engaging in activities which lead to abnormally high production costs at the same time that they are reducing discretionary expenses while the overall objective is to report as high as possible earnings for the period. The negative correlation between abnormal production costs and abnormal cash flows from operations $(-28 \%$, Pearson and $-19 \%$ Spearman) is consistent with the observation that overproduction has a negative effect on contemporaneous abnormal cash flows from operations.

For comparison purposes with previous SEO studies cited above, Table 4 reports the median return on assets (ROA) in the SEO year and the years immediately preceding and following it, where ROA is defined as income before extraordinary items divided by beginning of period total assets. Recall that these studies found positive abnormal performance in the SEO year, followed by negative abnormal performance in the subsequent year(s), which they interpret as evidence of upward earnings management followed by a predictable reversal. ${ }^{8}$ We find similar performance over time, with the reversal occurring over at least 2-3 years after the event, for both our overall sample (Panel A), and for various subsamples (Panels B thru F).

In summary, we document that firms use both accrual and real earnings management around SEOs, leading to positive abnormal performance in the SEO year and (perhaps inevitable) subsequent reversal. Our results are the first evidence to date of

\footnotetext{
${ }^{8}$ An alternative interpretation of this evidence is that firms choose to issue SEOs when they have been successful, and their subsequent performance decline is due to a natural regression to the mean (Ball and Shivakumar, 2007).
} 
real earnings management activities around SEOs. We now turn to examining how firms' earnings management behavior around SEOs has changed in response to the SarbanesOxley Act of 2002.

\subsection{The Sarbanes-Oxley Act of 2002}

Following our discussion in section 2.3, the apparent change in managerial behavior with respect to the alternative strategies employed to manage reported earnings after SOX motivates us to examine whether any such change can be observed for firms that are engaging in seasoned equity offerings. Specifically, we compare discretionary accruals, abnormal production costs, abnormal discretionary expenditures, abnormal CFO and our overall R_M Proxy measure in the pre-SOX period and subsequently in the postSOX period. If SOX induced a switch away from accrual-based earnings management towards real earnings management as recent evidence suggests (e.g., Cohen et al. 2007), we expect to see a reduction in discretionary accruals, increases in abnormal production costs, decreases in discretionary expenditures and an overall increase in $\mathrm{R} \_\mathrm{M}$ Proxy from the pre-SOX to the post-SOX period, for our SEO sample. One should note that price discounts, channel stuffing, and overproduction have a negative effect on contemporaneous abnormal $\mathrm{CFO}$, while reduction of discretionary expenditures has a positive effect. Thus, the net effect on abnormal CFO is ambiguous. The results are reported in Table 5.

The directions of the observed changes from the pre-SOX to post-SOX periods are consistent with our predictions, and three are highly statistically significant. Row 1 shows that while SEO firms still exhibit positive discretionary accruals after SOX, the average magnitude is reduced by almost $3 / 4^{\text {th }}$, $s$, and the change is highly statistically 
significant ( $\mathrm{t}$ statistic $=-8.54)$. Similarly, both abnormal CFO and abnormal production costs have increased significantly, with t-statistics of 4.19 and 3.95, respectively. Only the change in abnormal discretionary expenses is insignificant, but it is nevertheless negative, as expected. Thus, table shows that while SEO firms still use both types of earnings management in the post-SOX period, they have substituted away from accrualbased earnings management and towards real earnings management. We now investigate factors that determine why SEO firms use accrual versus real earnings management in the year of the SEO.

\subsection{Cross-sectional Determinants of Earnings Management Strategies for SEO Firms}

Table 2 showed that SEO firms have both abnormal accruals and abnormal real activities. Table 3 showed that the correlation between SEO firms' discretionary accruals and abnormal cash flow from operations is significantly negative. Together, we interpret these results as evidence that SEO firms tend to engage in both accrual and real earnings management activities, and they substitute between the two methods, consistent with Zang (2006). We now investigate the factors that influence their decisions to manage earnings, and if so, which method to use. To do so, we estimate a two-stage model using the Heckman (1979) method to control for firms' self-selection to manage reported earnings. In the first stage, we estimate a parsimonious selection model to explain firms' overall decisions to engage in earnings management or not. Next, conditional on this first stage analysis, in the second stage we analyze the factors determining the preference for real earnings management strategies as compared to accruals based ones. 


\subsubsection{First Stage Model to Explain the Decision to Manage Earnings}

Our first stage explains a firm's decision to manage reported earnings, regardless of which method is being used. The literature to date has identified certain managerial incentives to manage reported earnings. Recent studies, as reviewed by Fields et al. (2001) and Healy and Wahlen (1999), suggest that capital market incentives are the most significant ones in affecting earnings management activities. Therefore, we model a firm's decision to engage in earnings management activities as a function these incentives as well as equity based compensation, the firm's capital structure, performance, size and growth opportunities. Specifically, we estimate the following model:

$$
\begin{aligned}
& \text { Total_EM }=\beta_{0}+\beta_{1} H A B \_B E A T+\beta_{2} S H A R E S+\beta_{3} A N A L Y S T+\beta_{4} B O N U S+\beta_{5} O P T I O N \\
& \beta_{6} R O A+\beta_{7} M K T \_C A P T+\beta_{8} B \_M+\beta_{9} L E V E R A G E++\beta_{10} \Delta G D P+\varepsilon
\end{aligned}
$$

The dependent variable, Total_EM, is our measure of whether a firm is an earnings manager or not. It is defined as taking the value of 1 if the overall earnings management score is above the sample median in a given period and 0 otherwise. Recall that both abnormal accruals and our real earnings management proxies are regression residuals that are reported as a percentage of total assets. Thus, in order to obtain an overall earnings management activities score we aggregate a firm's abnormal accruals and its three real earnings management variables (abnormal CFO plus abnormal production costs and abnormal discretionary expenses).

In order to capture the capital market incentives, we include the variables HAB_BEAT and SHARES. Bartov et al. (2002) and Kasznik and McNichols (2002) 
provide evidence suggesting that firms that meet or beat analysts' earnings forecasts enjoy higher returns. Both Bartov et al. (2002) and Kasznik and McNichols (2002) document that this 'meet/beat' premium is higher for firms that constantly meet/beat analysts' earnings forecasts, i.e., 'habitual beaters'. Given this evidence, we conjecture that firms that repeatedly meet or beat earnings benchmarks will have stronger incentives to manage earnings to keep beating those earnings targets. We include $H A B \_B E A T$, defined as the frequency of meeting/beating analysts' earnings forecasts in the past four quarters to capture this specific capital market incentive, and we expect its coefficient to be positive.

Following Barton and Simko (2002) and Zang (2006), we include SHARES, the (natural logarithm of) number of shares outstanding. More shares outstanding requires more earnings management activities to achieve a given per share earnings target. Since this greater threshold may induce greater earnings management to achieve the target (Zang, 2006) or discourage earnings management because the target is more difficult to achieve (Barton and Simko, 2002), and since it is not clear whether the share effect would induce real or accrual earnings management, we make no directional prediction about SHARES.

There are two views advanced in the literature on the role of financial analysts who follow the firm and their effect on earnings management activities. On the one hand, financial analysts following the firm provide scrutiny and monitoring over firms' activities and thus constrain earnings management activities. On the other hand, analyst coverage also provides an incentive to meet or beat their forecasts, which may induce earnings management especially towards the end of the fiscal reporting period. Thus, we 
include ANALYST, the degree of analyst coverage (measured as the natural logarithm of the number of analysts covering the firm) in our choice model, but we are agnostic as to its sign.

Recent research suggests that compensation "excesses" are associated with earnings management activities. For example, Coffee (2003), Fuller and Jensen (2002), and Greenspan (2002), among others, assert that stock-based compensation and managerial ownership increased managers' incentives to hype earnings and, consequently, stock prices, which contributed to the 1990 s stock market bubble. ${ }^{9}$ Given the evidence in Cheng and Warfield (2005) and Bergstresser and Philippon (2005), we include in our model two variables related to performance-based compensation: proportions of bonus compensation and stock-based compensation. BONUS is the average bonus compensation as a proportion of total compensation received by the CEO and the CFO of a firm; and OPTION represents the Black-Scholes value of option compensation as a proportion of total compensation received by the $\mathrm{CEO}$ and the $\mathrm{CFO}$ of a firm..$^{10}$ The variables BONUS and $O P T I O N$ are included to proxy for compensation and incentives variables that may induce opportunistic behavior in managers. We obtain compensation data from the EXECUCOMP database which is available only from 1992

\footnotetext{
${ }^{9}$ For instance, Coffee (2003) asserts that the increase in stock-based executive compensation created an environment where managers became very sensitive to short-term stock performance. Greenspan (2002) opines that "the highly desirable spread of shareholding and options among business managers perversely created incentives to artificially inflate earnings to keep stock prices high and rising." Fuller and Jensen (2002, p. 42) also state that "[a]s stock options became an increasing part of executive compensation, and managers who made great fortunes on options became the stuff of legends, the preservation or enhancement of short-term stock prices became a personal (and damaging) priority for many CEOs and CFOs. High share prices and earnings multiples stoked already amply endowed managerial egos, and management teams proved reluctant to undermine their own stature by surrendering hard won records of quarter-over-quarter earnings growth.”

${ }^{10} \mathrm{We}$ also repeat the analyses by measuring BONUS and $O P T I O N$ variables for the top five executives of a firm, and the results are qualitatively unchanged.
} 
onwards. Thus, merging the sample used to test cross-sectional determinants of earnings management strategies consists of 1,172 SEO firm observations for the 1992 through 2006 period. $^{11}$

Finally, to control for capital structure, profitability, size, growth, and economy wide conditions we include LEVERAGE (the amount of debt in the firm's capital structure), $R O A$ (return on assets), $M K T \_C A P$ (log of market capitalization), $B \_M$ (book-to-market ratio), and $\triangle G D P$ as the change in the GDP as controls. We include these controls given the recent reviews of the earnings management literature (e.g., Healy and Whalen, 1999, Fields et al. 2001, among others).

The results of estimating equation (10) are reported in Table 6, Panel A. The table reports both the coefficients and their corresponding Z-statistics, the predicted sign as per the discussion above, and the marginal effect on the probability of managing earnings. Except for $B_{-} M$, all of the coefficient estimates are significant, and all have the hypothesized sign. Together, they explain over $50 \%$ of firms' decisions to manage earnings. In particular, the results show that as predicted, habitually beating earnings targets, having many shares outstanding, and having relatively large amounts of bonus and option compensation, all positively influence firms' tendency to manage earnings, while having a large analyst following reduces the tendency. The results also confirm the importance of managerial and capital market incentives, as HAB_BEAT, BONUS, and OPTION all have relatively large marginal effects on the decision to manage earnings.

\footnotetext{
${ }^{11}$ We have repeated the analysis documented in the previous sections using this reduced sample and the results we obtain are similar to those reported in the tables.
} 


\subsubsection{Second Stage Model to Explain the use of Real versus Accrual Earnings}

\section{Management}

Given that a firm has decided to manage reported earnings, we now seek to explain its choice of accrual versus real earnings management. Based on the widespread belief that real earnings management is more costly than accrual-based earnings management (e.g., Graham et al. 2005, Gunny 2006, and Zang 2006), and the fact that firms must use real management during the quarter but can wait until after the quarter to determine their accruals, we assume that firms prefer to use accrual-based earnings management activities to meet their reporting objectives. However, if firms are constrained from doing so or if the costs are perceived as too high, they substitute to real earnings management activities. Based on this assumption, we empirically model an SEO firm's choice to use real or accrual earnings management tools as a function of its ability to use accrual-based earnings management and the costs of doing so.

We represent a firm's ability to manage earnings using accruals by $N O A$, the firm's net operating assets position (following Barton and Simko, 2002). Barton and Simko argue that since the balance sheet accumulates the effects of prior accounting choices, the level of NOA (at least partly) reflects previous earnings management: higher current NOA indicating greater past earnings management. Thus, they predict that managers' ability to upwardly manage reported earnings by manipulating accruals is negatively related to their firms' level of NOA. Consistent with their predictions, they find that the probability of beating analysts' earnings expectations is negatively related to the level of NOA. Based on their analysis, we predict that an SEO firm's tendency to use 
real earnings management is positively related to $N O A$, since higher NOA firms substitute away from accruals-based earnings management.

The costs of using accrual-based earnings management include the scrutiny provided by the capital markets, the potential penalty of detection, and the difficulty of achieving a given earnings target. Based on the survey evidence in Graham et al. (2005), we assume that firms facing greater scrutiny prefer to use real management. Graham et al. find that managers prefer real earnings management to accruals management, because real earnings management can be indistinguishable from optimal business decisions, and thus more difficult to detect. Avoiding detection is likely to be a stronger motivation the greater the scrutiny. Following Gunny (2005) and Zang (2006), we assume that scrutiny increases with the presence of a Big 8 auditor, and with the auditor's experience (tenure) at the client. Thus, we include $B I G 8$, a dummy variable for whether a firm has a Big 8 auditor, and $A U D I T-T E N U R E$, the (natural logarithm of) the number years the auditor has audited the firm. We predict that the tendency for SEO firms to use real earnings management is positively related to both $B I G 8$ and $A U D I T+T E N U R E$.

The primary penalty for earnings manipulation is litigation. Since accrual-based manipulation is more likely than real activities manipulation to be detected and therefore punished, greater perceived litigation penalties should increase the tendency for real earnings management. To capture expected litigation penalties, we include two dummy variables. The first, LITIGATION, equals one if a firm is in a high litigation industry, and zero otherwise. Following Barton and Simko (2002) and Zang (2006), high litigation industries are SIC codes 2833-2836, 8731-8734, 7371-7379, 3570-3577, and 3600-3674. These SIC codes correspond, respectively, to the following industries: 
pharmaceuticals/biotechnology, computers, and electronics. The second, SOX, based on our findings in Section 4.2 above, equals one if the SEO observation falls within the PostSOX period and zero in the Pre-SOX period. We predict that the tendency for SEO firms to use real earnings management is positively related to both LITIGATION and SOX. Thus, our model of SEO firms' real earnings management choices is:

Real Earnings Management $=\beta_{0}+\beta_{1}$ BIG8 $+\beta_{2}$ AUDIT_TENURE $+\beta_{3}$ LITIGATION + $\beta_{4} N O A+\beta_{5} S O X+\beta_{6}$ INVS_MILLS $+\varepsilon$

We estimate equation (11) as a Probit model, to account for SEO firms' differing preference of real over accrual earnings management, with the dependent variable defined as follows:

1 if a firm's real earnings management proxy $>$ the sample median real earnings management proxy and 0 otherwise.

The structure of our Probit model is such that a factor that is hypothesized to increase the tendency for real earnings management it is expected to have a positive coefficient. Thus, BIG8, AUDIT_TENURE, LITIGATION, NOA, and SOX are all expected to have positive coefficients.

The results of estimating equation (11) are reported in Table 6, Panel B. Analogous to Panel A, the table reports both the coefficients and their corresponding Z-statistics, the predicted sign as per the discussion above, and the marginal effect on the probability of the firm using real earnings management.. Thus, for example, having a Big 8 auditor increases the probability by about $7 \%$. As hypothesized, we find that the presence of a 
Big 8 auditor, auditor tenure, being in a high litigation industry, the level of net operating assets, and the Sarbanes-Oxley Act are all associated with an increased tendency to use real earnings management around the time of the SEO. The greatest marginal effect on using real earnings management comes from the firm's NOA position and SOX, supporting the evidence in Barton and Simko (2002) and Cohen, Dey, and Lys (2007), respectively. Overall, the model is highly significant, and explains about $68 \%$ of SEO firms' real earnings management decisions.

In summary, the two-stage model is highly effective in explaining both firms' decisions to manage earnings, and, given that they do so, whether they use real or accrual-based earnings management. We emphasize that although we use our model to study SEOs, the model could be used more generally to study how firms tradeoff between the two methods of earnings management, an important topic for future research.

\section{Conclusion}

We examine earnings management behavior around SEOs, by focusing on both real activities and accrual-based manipulation, and how this behavior varies over time and cross-sectionally. Although research has addressed the issues of earnings management around SEOs and earnings management via real activities manipulation, ours is the first paper to put these two issues together. To capture accruals-based earnings management we use the modified cross-sectional Jones model (Jones 1991) as described in Dechow et al. (1995). To capture real earnings management activities, we follow Roychowdhury (2006) and estimate abnormal levels of cash flows from operations, 
discretionary expenses (the sum of advertising, R\&D, and SG\&A), and production costs. We make three contributions to the literature.

First, we document that firms use real, as well as accrual-based, earnings management tools around SEOs. Second, consistent with the expectation that SOX has made accrual-based earnings management more costly, we find that firms have substituted from accrual to real earnings management after SOX. Finally, we show how the tendency for firms to tradeoff real versus accrual-based earnings management activities around SEO's varies cross-sectionally. We find that firms' choices vary predictably as a function of the firm's ability to use accrual management and the costs of doing so. Our model is a first step in examining how firms tradeoff between real versus accrual methods of earnings management. This remains an important topic for future research. 


\section{References}

Ball R., and L. Shivakumar. 2007. Earnings Quality at Initial Public Offerings. Journal of Accounting and Economics, Forthcoming.

Barton, J., and P.J. Simko. 2002. The Balance Sheet as an Earnings Management Constraint. The Accounting Review 77: 1-27.

Bartov, E., D. Givoly, and C. Hayn. 2002. The Rewards to Meeting or Beating Analysts' Forecasts. Journal of Accounting and Economics 33: 173-204.

Bergstresser, D., and T. Philippon. 2006. CEO Incentives and Earnings Management. Journal of Financial Economics 80, 511-529.

Cheng, Q., and T.D. Warfield. 2005. Equity Incentives and Earnings Management. The Accounting Review 80: 441-476.

Coffee, J., 2003. What causes Enron? A Capsule Social and Economic History of the 1990s. Working Paper, Columbia University.

Cohen, D., A. Dey, and T. Lys. 2007. Real and Accrual Based Earnings Management in the Pre and Post Sarbanes Oxley Periods. The Accounting Review, Forthcoming.

Dechow, P.M., S.P. Kothari, and R. Watts. 1998. The Relation between Earnings and Cash Flows. Journal of Accounting and Economics 25: 133-168.

Dechow, P. M., R. G. Sloan, and A. P. Sweeney. 1995. Detecting Earnings Management. The Accounting Review 70: 193-225.

DeFond, M. L., and J. Jiambalvo. 1994. Debt Covenant Effects and the Manipulation of Accruals. Journal of Accounting and Economics 17: 145-176.

Fuller, J., and Michael C. Jensen (2002), Just say no to Wall Street, Journal of Applied Corporate Finance 14: 41-46.

DuCharme, L. L., P.H. Malatesta, and S. E. Sefcik. 2004. Earnings management, stock issues, and shareholder lawsuits. Journal of Financial Economics 71: 27-49.

Graham, J. R., C. R. Harvey, and S. Rajgopal. 2005. The Economic Implications of Corporate Financial Reporting. Journal of Accounting and Economics 40: 3-73.

Gunny, K. 2005. What are the Consequences of Real Earnings Management? Working Paper, University of Colorado.

Greenspan, A., 2002. Federal Reserve Board's Semiannual Monetary Policy Report to the Congress. Testimony before the Committee on Banking, Housing, and Urban Affairs, U.S. Senate, July 16. 
Jones, J. 1991. Earnings Management during Import Relief Investigations. Journal of Accounting Research 29: 193-228.

Kasznik R. and M. F. McNichols. 2002. Does meeting expectations matter? Evidence from analyst forecast revisions and share prices. Journal of Accounting Research 40 (3) 727-759.

Kothari, S.P., A.J. Leone, and C. Wasley. 2005. Performance Matched Discretionary Accrual Measures. Journal of Accounting and Economics 39: 163-197.

Myer, S. and N. Majluf. 1984. Corporate financing and investment decisions when firms have information that investors do not have. Journal of Financial Economics 13: 187221.

Rangan, S., 1998. Earnings before seasoned equity offerings: are they overstated? Journal of Financial Economics 50: 101-122.

Roychowdhury, S. 2006. Earnings Management through Real Activities Manipulation. Journal of Accounting and Economics 42: 335-370.

Shivakumar, L. 2000. Do Firms Mislead Investors by Overstating Earnings before Seasoned Equity Offerings? Journal of Accounting and Economics 29: 339-371.

Teoh, S. H., Welch, I., and T. J. Wong. 1998. Earnings management and the long-run performance of seasoned equity offerings. Journal of Financial Economics 50: 63100.

Zang, A. Z. 2006. Evidence on the Tradeoff between Real Manipulation and Accrual Manipulation. Working Paper, Duke University. 
Table 1. Descriptive statistics for sample firms conducting SEOs during 1987-2006.

Panel A: Size characteristics

\begin{tabular}{lccccc} 
& $\begin{array}{c}\text { Total Assets } \\
\text { (\$ mil.) }\end{array}$ & $\begin{array}{c}\text { Market } \\
\text { Value } \\
\text { (\$ mil.) }\end{array}$ & $\begin{array}{c}\text { Book-to- } \\
\text { Market }\end{array}$ & $\begin{array}{c}\text { Offer } \\
\text { Amount } \\
\text { (\$ mil.) }\end{array}$ & $\begin{array}{c}\text { Offer } \\
\text { Size }\end{array}$ \\
\hline Mean & 422.10 & 543.87 & 0.43 & 85.64 & 0.28 \\
Median & 118.62 & 186.29 & 0.34 & 52.90 & 0.23 \\
Std. Dev. & 913.23 & 1704.72 & 0.41 & 172.18 & 0.24
\end{tabular}

Panel B: Time distribution

\begin{tabular}{|c|c|c|c|}
\hline Year & Freq & $\%$ & Cum. \% \\
\hline 1987 & 86 & $5.69 \%$ & $5.69 \%$ \\
\hline 1988 & 49 & $3.24 \%$ & $8.93 \%$ \\
\hline 1989 & 59 & $3.90 \%$ & $12.84 \%$ \\
\hline 1990 & 42 & $2.78 \%$ & $15.62 \%$ \\
\hline 1991 & 103 & $6.82 \%$ & $22.44 \%$ \\
\hline 1992 & 112 & $7.41 \%$ & $29.85 \%$ \\
\hline 1993 & 105 & $6.95 \%$ & $36.80 \%$ \\
\hline 1994 & 89 & $5.89 \%$ & $42.69 \%$ \\
\hline 1995 & 107 & $7.08 \%$ & $49.77 \%$ \\
\hline 1996 & 114 & $7.54 \%$ & $57.31 \%$ \\
\hline 1997 & 80 & $5.29 \%$ & $62.61 \%$ \\
\hline 1998 & 74 & $4.90 \%$ & $67.50 \%$ \\
\hline 1999 & 95 & $6.29 \%$ & $73.79 \%$ \\
\hline 2000 & 58 & $3.84 \%$ & $77.63 \%$ \\
\hline 2001 & 72 & $4.77 \%$ & $82.40 \%$ \\
\hline 2002 & 83 & $5.49 \%$ & $87.89 \%$ \\
\hline 2003 & 64 & $4.24 \%$ & $92.12 \%$ \\
\hline 2004 & 54 & $3.57 \%$ & $95.70 \%$ \\
\hline 2005 & 43 & $2.85 \%$ & $98.54 \%$ \\
\hline 2006 & 22 & $1.46 \%$ & $100.00 \%$ \\
\hline Total & 1,511 & $100 \%$ & \\
\hline
\end{tabular}


Panel C: Industry (SIC) distribution

\begin{tabular}{|c|c|c|c|}
\hline Industry & $\begin{array}{c}\text { Two-digit SIC } \\
\text { codes }\end{array}$ & Freq & $\%$ \\
\hline Oil and Gas & 13,29 & 82 & 5.41 \\
\hline Food products & 20 & 19 & 1.25 \\
\hline Paper and paper products & $24-27$ & 49 & 3.17 \\
\hline Chemical products & 28 & 139 & 9.24 \\
\hline Manufacturing & $30-34$ & 55 & 3.65 \\
\hline $\begin{array}{l}\text { Computer equipment and } \\
\text { services }\end{array}$ & 35,73 & 200 & 13.25 \\
\hline Electronic equipment & 36 & 144 & 9.57 \\
\hline Transportation & $37,39,40-42,44,45$ & 63 & 4.17 \\
\hline Scientific instruments & 38 & 99 & 6.54 \\
\hline Communications & 48 & 32 & 2.15 \\
\hline $\begin{array}{l}\text { Electric, gas, and sanitary } \\
\text { services }\end{array}$ & 49 & 158 & 10.49 \\
\hline Durable goods & 50 & 53 & 3.43 \\
\hline Retail & $53,54,56,57,59$ & 59 & 3.94 \\
\hline $\begin{array}{l}\text { Eating and drinking } \\
\text { establishments }\end{array}$ & 58 & 22 & 1.47 \\
\hline Entertainment services & $70,78,79$ & 32 & 2.07 \\
\hline Health & 80 & 33 & 2.16 \\
\hline All others & & 272 & 18.04 \\
\hline Total & & 1,511 & $100 \%$ \\
\hline
\end{tabular}

Notes to Table 1: Total assets are beginning of period total assets (Compustat data item \#6); Market value refers to market value of equity and is calculated as the closing price at fiscal year-end times the number of shares outstanding at fiscal year-end (Compustat annual data item \#199 times Compustat annual data item \#25); Book-to-Market ratio, where the book value of common equity (Compustat annual data item \#60) is divided by market value of equity (calculated as the closing price at fiscal year-end times the number of shares outstanding at fiscal year-end (Compustat annual data item \#199 times Compustat annual data item \#25)); Offer amount is the dollar amount of the seasoned equity offering; Offering Size is computed as the number of shares offered divided by the number of shares outstanding before the seasoned equity offering. 
Table 2. Accrual-based and Real Earnings Management Proxies around Seasoned Equity Offerings

\begin{tabular}{|c|c|c|c|c|c|c|c|}
\hline Year & -3 & -2 & -1 & $\mathbf{0}$ & 1 & 2 & 3 \\
\hline Discretionary accruals & $\begin{array}{l}-0.010 \\
(-0.86)\end{array}$ & $\begin{array}{l}0.001 \\
(0.98)\end{array}$ & $\begin{array}{l}0.008 \\
(1.12)\end{array}$ & $\begin{array}{c}0.0153 \\
(3.63) * * *\end{array}$ & $\begin{array}{c}0.009 \\
(1.79)^{*}\end{array}$ & $\begin{array}{l}-0.004 \\
(-1.01)\end{array}$ & $\begin{array}{l}-0.007 \\
(-1.82)^{*}\end{array}$ \\
\hline Abnormal cash flows & -0.003 & -0.017 & -0.025 & -0.046 & -0.031 & -0.017 & -0.001 \\
\hline from operations & $(-0.09)$ & $(-1.79)^{*}$ & $(-2.14)^{*}$ & $(-5.89) * * *$ & $(2.58) * * *$ & $(-1.74)^{*}$ & $(-0.31)$ \\
\hline $\begin{array}{l}\text { Abnormal production } \\
\text { costs }\end{array}$ & $\begin{array}{l}-0.004 \\
(-0.68)\end{array}$ & $\begin{array}{l}-0.009 \\
(-0.86)\end{array}$ & $\begin{array}{l}-0.011 \\
(-1.41)\end{array}$ & $\begin{array}{c}0.043 \\
(4.96) * * *\end{array}$ & $\begin{array}{l}-0.005 \\
(-1.09)\end{array}$ & $\begin{array}{l}-0.014 \\
(-1.04)\end{array}$ & $\begin{array}{l}-0.007 \\
(-0.54)\end{array}$ \\
\hline $\begin{array}{l}\text { Abnormal discretionary } \\
\text { expenses }\end{array}$ & $\begin{array}{l}-0.008 \\
(2.14)^{* *}\end{array}$ & $\begin{array}{c}-0.004 \\
(-1.97)^{*}\end{array}$ & $\begin{array}{l}-0.001 \\
(-1.39)\end{array}$ & $\begin{array}{c}-0.004 \\
(-2.09) * *\end{array}$ & $\begin{array}{c}0.001 \\
(2.46)^{* *}\end{array}$ & $\begin{array}{l}0.003 \\
(1.61)\end{array}$ & $\begin{array}{l}-0.001 \\
(-0.97)\end{array}$ \\
\hline R_M Proxy & $\begin{array}{l}0.004 \\
(0.97)\end{array}$ & $\begin{array}{l}0.006 \\
(1.62)^{*}\end{array}$ & $\begin{array}{c}0.017 \\
(2.36)^{* *}\end{array}$ & $\begin{array}{c}0.057 \\
(4.06) * * *\end{array}$ & $\begin{array}{l}0.007 \\
(1.86)^{*}\end{array}$ & $\begin{array}{l}0.003 \\
(0.67)\end{array}$ & $\begin{array}{l}0.001 \\
(0.37)\end{array}$ \\
\hline
\end{tabular}

Notes to Table 3: This table reports time series of accrual-based and real earnings management proxies from year -3 to year +3 relative to the seasoned equity offering (year 0). Discretionary accruals are estimated using the modified Jones Model; Abnormal cash from operations are estimated as the deviations from the predicted values from the following industry-year regression: $\frac{C F O_{i t}}{\text { Assets }_{i t,-1}}=k_{1 t} \frac{1}{\text { Assets }_{i, t-1}}+k_{2} \frac{\text { Sales }_{i t}}{\text { Assets }_{i, t-1}}+k_{3} \frac{\Delta \text { Sales }_{i t}}{\text { Assets }_{i, t-1}}+\varepsilon_{i t}$; CFO are cash flow from operations

(Compustat data item 308 -Compustat data item 124; Sales are annual sales revenues (Compustat data item 12) and Assets are total assets (Compustat data item 6); Abnormal production costs are estimated as the deviations from the predicted values from the following industry-year regression: $\frac{P R O D \quad j q}{\text { Asset } \quad j q-1}=\delta_{j q}+\alpha_{0} \frac{1}{\text { Asset } j q-1}+\beta_{1} \frac{(\Delta \text { Sales } j q)}{\text { Asset } j q-1}+\beta_{2} \frac{\text { SALES }{ }_{j q}{ }_{j q}{ }_{j q}-1}{\text { Asset }_{j q}} ;$ PROD are production costs defined as the sum of costs of goods sold

(Compustat data item 41) and change in inventory during the year (Compustat data item 3); Abnormal discretionary expenses are estimated as the deviations from the predicted values from the following industry-year regression: $\frac{D \text { iscExp } p_{i t}}{\text { Assets }_{i, t-1}}=k_{1 t} \frac{1}{A \text { s ets }_{i, t-1}}+k_{2} \frac{\text { Sa les } s_{i, t-1}}{A \text { ssets } s_{i, t-1}}+\varepsilon_{i t}$; DISCEXP are discretionary expenses during the year and are defined as the sum of as the sum of advertising expenses (Compustat data item 45), R\&D expenses (Compustat data item 46) and SG\&A (Compustat data item 189). R_M Proxy is the sum of abnormal cash flows from operations, abnormal production costs and abnormal discretionary expenses. We multiply abnormal cash flows from operations and abnormal discretionary expenses by negative one such that the sum of the three variables will be indicative of overall real earnings management. 
Table 3. Correlation Matrix among Earnings Management Proxies

\begin{tabular}{|l|c|r|r|c|}
\hline & $D A$ & $R \_C F O$ & $R \_P R O D$ & $R \_D I S X$ \\
\hline$D A$ & 1 & $-0.252 * * *$ & $0.031 * * *$ & $-0.179 * * *$ \\
\hline$R \_C F O$ & $-0.228 * * *$ & 1 & $-0.282 * * *$ & $-0.165 * * *$ \\
\hline$R \_P R O D$ & $0.029 * * *$ & $-0.189 * * *$ & 1 & $-0.276 * * *$ \\
\hline$R \_D I S X$ & $-0.152 * * *$ & $-0.233 * * *$ & $-0.198 * * *$ & 1 \\
\hline
\end{tabular}

*** Significant at the $1 \%$ level, ** Significant at the 5\% level, * Significant at the $10 \%$

Notes to Table 2: This table reports Pearson (above the diagonal) and Spearman (below the diagonal) correlation for the sample of seasoned equity firms over 1987-2006.

$D A$ are discretionary accruals computed using the Modified Jones model; $R \_C F O$ represents the level of abnormal cash flows from operations; $R \_P R O D$ represents the level of abnormal production costs, where production costs are defined as the sum of cost of goods sold and the change in inventories; $R$ DISX represents the level of abnormal discretionary expenses, where discretionary expenses are the sum of advertising expenses (annual Compustat data item 45 ), R\&D expenses (annual Compustat data item 46) and SG\&A expenses (annual Compustat data 189). 
Table 4. Performance around Seasoned Equity Offerings

Panel A: Return on Assets performance

\begin{tabular}{llllllll} 
Year & $\mathbf{- 3}$ & $\mathbf{- 2}$ & $\mathbf{- 1}$ & $\mathbf{0}$ & $\mathbf{1}$ & $\mathbf{2}$ & \multicolumn{3}{l}{} \\
\hline Industry Adjusted ROA & 0.009 & 0.012 & 0.023 & 0.031 & -0.014 & -0.013 & -0.009 \\
& $(1.98)^{*}$ & $(2.12)^{* *}$ & $(3.49)^{* * *}$ & $(5.97)^{* * *}$ & $(3.67)^{* * *}$ & $(-2.83)^{* * *}$ & $(-1.85)^{*}$ \\
Industry Adjusted $\Delta$ ROA & & -0.000 & 0.002 & 0.019 & -0.017 & -0.009 & -0.002 \\
& & $(-0.02)$ & $(0.96)$ & $(5.41)^{* * *}$ & $(4.16)^{* * *}$ & $(2.59)^{* * *}$ & $(-1.89)^{*}$
\end{tabular}

Panel B: Return on Assets performance, for the extreme quartile of discretionary accruals

\begin{tabular}{llllllll} 
Year & $\mathbf{- 3}$ & $\mathbf{- 2}$ & $\mathbf{- 1}$ & $\mathbf{0}$ & $\mathbf{1}$ & $\mathbf{2}$ & $\mathbf{3}$ \\
\hline Industry Adjusted ROA & 0.008 & 0.018 & 0.028 & 0.036 & -0.023 & -0.017 & -0.008 \\
& $(1.76)^{*}$ & $(2.67)^{* * *}$ & $(3.48)^{* * *}$ & $(6.05)^{* * *}$ & $(-3.48)^{* * *}$ & $(-2.95)^{* * *}$ & $(-1.82)^{*}$ \\
Industry Adjusted $\Delta$ ROA & & 0.006 & 0.003 & 0.009 & -0.022 & -0.012 & -0.008 \\
& & $(1.42)$ & $(0.62)$ & $(2.94)^{* * *}$ & $(-4.09)^{* * *}$ & $(-3.64)^{* * *}$ & $(-1.99)^{*}$
\end{tabular}

Panel C: Return on Assets performance, for the extreme quartile of abnormal cash flow from operations

\begin{tabular}{llllllll} 
Year & $\mathbf{- 3}$ & $\mathbf{- 2}$ & $\mathbf{- 1}$ & $\mathbf{0}$ & $\mathbf{1}$ & $\mathbf{2}$ & $\mathbf{3}$ \\
\hline Industry Adjusted ROA & 0.006 & 0.013 & 0.018 & 0.037 & -0.021 & -0.019 & -0.007 \\
& $(1.06)$ & $(1.99)^{*}$ & $(3.03)^{* * *}$ & $(4.19)^{* * *}$ & $(-3.16)^{* * *}$ & $(-2.87)^{* * * *}$ & $(-1.24)$ \\
Industry Adjusted $\Delta$ ROA & & 0.004 & 0.008 & 0.011 & -0.024 & -0.017 & -0.006 \\
& & $(0.98)$ & $(1.08)$ & $(3.07)^{* * *}$ & $(-4.09)^{* * *}$ & $(2.69)^{* *}$ & $(-1.79)^{*}$
\end{tabular}


Panel D: Return on Assets performance, for the extreme quartile of abnormal production costs

\begin{tabular}{llllllll} 
Year & $\mathbf{- 3}$ & $\mathbf{- 2}$ & $\mathbf{- 1}$ & $\mathbf{0}$ & $\mathbf{1}$ & $\mathbf{2}$ & $\mathbf{3}$ \\
\hline Industry Adjusted ROA & 0.008 & 0.011 & 0.018 & 0.027 & -0.035 & -0.027 & -0.019 \\
& $(1.09)$ & $(1.43)$ & $(2.07)^{* *}$ & $(4.26)^{* * *}$ & $(-4.69)^{* * *}$ & $(-3.69)^{* * *}$ & $(-3.89)^{* * *}$ \\
Industry Adjusted $\Delta$ ROA & & 0.002 & 0.003 & 0.021 & -0.037 & -0.012 & -0.007 \\
& & $(0.54)$ & $(1.09)$ & $(3.57)^{* * *}$ & $(-4.62)^{* * *}$ & $(-3.18)^{* * *}$ & $(-1.63)^{*}$
\end{tabular}

Panel E: Return on Assets performance, for the extreme quartile of abnormal discretionary expenses

\begin{tabular}{llllllll} 
Year & $\mathbf{- 3}$ & $\mathbf{- 2}$ & $\mathbf{- 1}$ & $\mathbf{0}$ & $\mathbf{1}$ & $\mathbf{2}$ & $\mathbf{3}$ \\
\hline Industry Adjusted ROA & 0.005 & 0.006 & 0.012 & 0.019 & -0.017 & -0.013 & -0.018 \\
& $(0.96)$ & $(1.04)$ & $(2.83)^{* *}$ & $(2.96)^{* * *}$ & $(-3.09)^{* * *}$ & $(-4.06)^{* * *}$ & $(-3.46)^{* * *}$ \\
& & & & & & & \\
Industry Adjusted $\Delta$ ROA & & 0.002 & 0.004 & 0.024 & -0.027 & -0.018 & -0.007 \\
& & $(0.74)$ & $(1.26)$ & $(3.97)^{* * *}$ & $(-4.68)^{* * *}$ & $(-3.47)^{* * *}$ & $(-1.85)^{*}$
\end{tabular}

Panel F: Return on Assets performance, for the extreme quartile of overall real earnings Management Activities (R_M Proxy)

\begin{tabular}{llllllll} 
Year & $\mathbf{- 3}$ & $\mathbf{- 2}$ & $\mathbf{- 1}$ & $\mathbf{0}$ & $\mathbf{1}$ & $\mathbf{2}$ & $\mathbf{3}$ \\
\hline Industry Adjusted ROA & 0.005 & 0.008 & 0.015 & 0.019 & -0.021 & -0.017 & -0.011 \\
& $(0.67)$ & $(0.96)$ & $(2.97)^{* * *}$ & $(3.06)^{* * *}$ & $(-3.91)^{* * *}$ & $(-2.84)^{* * *}$ & $(-3.46)^{* * *}$ \\
Industry Adjusted $\Delta$ ROA & & 0.001 & 0.003 & 0.017 & -0.029 & -0.013 & -0.004 \\
& & $(0.62)$ & $(1.31)$ & $(3.23)^{* * *}$ & $(-3.91)^{* * *}$ & $(-2.94)^{* * *}$ & $(1.74)^{*}$
\end{tabular}


$I N D \_R O A$ is the industry adjusted return on assets, where the return on assets is defined as income before extraordinary items divided by beginning of period total assets less the industry median; Discretionary accruals are estimated using the modified Jones Model; Abnormal cash from operations are estimated as the deviations from the predicted values from the following industry-year regression: $\frac{C F O_{i t}}{A s s e t s}=k_{1 t} \frac{1}{A s s e t s}+k_{2} \frac{\text { Sales }_{i t}}{\text { Assets }}+k_{3} \frac{\Delta \text { Sales }_{i t}}{A s s e t s}+\varepsilon_{i t}$; $C F O$ are cash flow from

operations (Compustat data item 308 -Compustat data item 124; Sales are annual sales revenues (Compustat data item 12) and Assets are total assets (Compustat data item 6); Abnormal production costs are estimated as the deviations from the predicted values from the following industry-year regression:

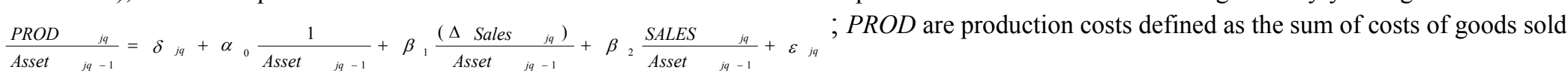

(Compustat data item 41) and change in inventory during the year (Compustat data item 3); Abnormal discretionary expenses are estimated as the deviations from the predicted values from the following industry-year regression: $\frac{D i s c E x p_{i t}}{A s s e t s i t-1}=k_{1 t} \frac{1}{A s s e t s}+k_{2} \frac{\text { Sales } s_{i, t-1}}{A s s e t s}+\varepsilon_{i t}$; DISCEXP are discretionary expenses during the year and are defined as the sum of as the sum of advertising expenses (Compustat data item 45), R\&D expenses (Compustat data item 46) and SG\&A (Compustat data item 189). $R$ M Proxy is the sum of abnormal cash flows from operations, abnormal production costs and abnormal discretionary expenses. We multiply abnormal cash flows from operations and abnormal discretionary expenses by negative one such that the sum of the three variables will be indicative of overall real earnings management. 
Table 5. The Sarbanes Oxley Act and Accrual-based and Real Earnings Management proxies in the Year of Seasoned Equity Offering

\begin{tabular}{lccc} 
& $\begin{array}{c}\text { Prior to SOX (1) } \\
\text { 1998-2001 }\end{array}$ & $\begin{array}{c}\text { After Sox (2) } \\
\mathbf{2 0 0 3 - 2 0 0 6}\end{array}$ & \multicolumn{1}{c}{ Difference (2) - (1) } \\
& & & \\
& 0.047 & 0.013 & -0.034 \\
Discretionary accruals & $(6.98)^{* * *}$ & $(4.23)^{* * *}$ & $(-8.54)^{* * *}$ \\
& -0.032 & -0.009 & 0.021 \\
$\begin{array}{l}\text { Abnormal cash flows } \\
\text { from operations }\end{array}$ & $(-4.32)^{* * *}$ & $(-1.97)^{*}$ & $(4.19)^{* * *}$ \\
& & & \\
Abnormal production & -0.032 & 0.021 & 0.043 \\
costs & $(-3.09)^{* * *}$ & $(4.21)^{* * *}$ & $(3.95)^{* * *}$ \\
$\begin{array}{l}\text { Abnormal discretionary } \\
\text { expenses }\end{array}$ & -0.008 & -0.013 & -0.005 \\
R_M Proxy & $(-1.87)^{*}$ & $(-2.49)^{* *}$ & $(1.07)$ \\
& 0.019 & 0.033 & 0.014 \\
No. of SEOs & $(3.27)^{* * * *}$ & $(4.67)^{* * *}$ & $(3.09)^{* * *}$ \\
& 299 & 183 & 116
\end{tabular}


Notes to Table 5:

This table reports properties of accrual-based and real earnings management in the year of the seasoned equity offering (year 0) prior to SOX and post-SOX. Seasoned equity offerings occurring prior to 2002 are classified as PRIOR to SOX and seasoned equity offerings occurring after 2003 are classified as AFTER SOX. Discretionary accruals are estimated using the modified Jones Model; Abnormal cash from operations are estimated as the deviations from the predicted values from the following industry-year regression:

$$
\frac{\text { CFO }_{i t}}{\text { Assets }_{i, t-1}}=k_{1 t} \frac{1}{\text { Assets }_{i, t-1}}+k_{2} \frac{\text { Sales }_{i t}}{\text { Assets }_{i, t-1}}+k_{3} \frac{\Delta \text { Sales }_{i t}}{\text { Assets }_{i, t-1}}+\varepsilon_{i t}
$$
; $\mathrm{CFO}$ are cash flow from operations (Compustat data

item 308 -Compustat data item 124; Sales are annual sales revenues (Compustat data item 12) and Assets are total assets (Compustat data item 6); Abnormal production costs are estimated as the deviations from the predicted values from the following industry-year regression:

$\frac{P R O D \quad j q}{\text { Asset } \quad j q-1}=\delta_{j q}+\alpha_{0} \frac{1}{\text { Asset } j q-1}+\beta_{1} \frac{(\Delta \text { Sales } j q)}{\text { Asset } j q-1}+\beta_{2} \frac{\text { SALES }{ }_{j q}{ }_{j q}}{\text { Asset }{ }_{j q-1}}+\varepsilon_{j q} ;$ PROD are production costs defined as the sum of costs of goods sold

(Compustat data item 41) and change in inventory during the year (Compustat data item 3); Abnormal discretionary expenses are estimated as the deviations from the predicted values from the following industry-year regression: $\frac{D \text { iscExp } p_{i t}}{A s s e t s i t-1}=k_{1 t} \frac{1}{A s s e t s}+k_{2} \frac{\text { Sales } s_{i, t-1}}{A s s e t s}+\varepsilon_{i t}$; DISCEXP are discretionary expenses during the year and are defined as the sum of as the sum of advertising expenses (Compustat data item 45), R\&D expenses (Compustat data item 46) and SG\&A (Compustat data item 189). $R$ M Proxy is the sum of abnormal cash flows from operations, abnormal production costs and abnormal discretionary expenses. We multiply abnormal cash flows from operations and abnormal discretionary expenses by negative one such that the sum of the three variables will be indicative of overall real earnings management. 
Table 6: Cross-sectional determinants of earnings management strategies in the year of the SEO

Panel A: Determinants of Overall Earnings Management Activities (First Stage)

\begin{tabular}{|c|c|c|c|}
\hline & Predicted Sign & $\begin{array}{l}\text { Coeff. } \\
\text { (Z- Statistic) }\end{array}$ & $\begin{array}{c}\text { Marginal Effect } \\
(\%)\end{array}$ \\
\hline HAB_BEAT & + & $\begin{array}{c}0.043 \\
(5.67)^{* * *}\end{array}$ & 18.09 \\
\hline SHARES & + & $\begin{array}{c}0.067 \\
(4.39)^{* * *}\end{array}$ & 9.47 \\
\hline ANALYST & $-/+$ & $\begin{array}{c}-0.005 \\
(-3.67)^{* * *}\end{array}$ & 6.12 \\
\hline BONUS & + & $\begin{array}{c}0.027 \\
(3.08)^{* * *}\end{array}$ & 11.32 \\
\hline OPTION & + & $\begin{array}{c}0.074 \\
(4.03)^{* * *}\end{array}$ & 16.32 \\
\hline ROA & $?$ & $\begin{array}{c}0.034 \\
(2.76)^{* *}\end{array}$ & 5.32 \\
\hline MKT_CAP & $?$ & $\begin{array}{c}0.001 \\
(1.99)^{* *}\end{array}$ & 2.67 \\
\hline B_M & $?$ & $\begin{array}{r}-0.002 \\
(1.09)\end{array}$ & 2.74 \\
\hline LEVERAGE & $?$ & $\begin{array}{c}0.004 \\
(2.08)^{* *}\end{array}$ & 4.97 \\
\hline$\Delta$ GDP & $?$ & $\begin{array}{c}0.001 \\
(1.67)^{*}\end{array}$ & 2.09 \\
\hline No. of Observations & 1,172 & & \\
\hline Likelihood ratio $\chi^{2}$ & 421.67 & & \\
\hline Maximum Likelihood $\mathbf{R}^{2}$ & 0.581 & & \\
\hline
\end{tabular}




\section{Panel B: Determinants of Real Earnings Management Activities (Second Stage)}

\begin{tabular}{|c|c|c|c|}
\hline & Predicted Sign & $\begin{array}{l}\text { Coeff. } \\
\text { (Z- Statistic) }\end{array}$ & $\begin{array}{c}\text { Marginal Effect } \\
(\%)\end{array}$ \\
\hline BIG8 & + & $\begin{array}{c}0.031 \\
(3.09)^{* * *}\end{array}$ & 7.39 \\
\hline AUDIT_TENURE & $+/-$ & $\begin{array}{c}0.003 \\
(1.69)^{*}\end{array}$ & 6.07 \\
\hline LITIGATION & + & $\begin{array}{c}0.024 \\
(4.51)^{* * *}\end{array}$ & 6.12 \\
\hline NOA & + & $\begin{array}{c}0.033 \\
(5.74)^{* * *}\end{array}$ & 14.69 \\
\hline SOX & + & $\begin{array}{c}0.006 \\
(3.79)^{* * *}\end{array}$ & 15.96 \\
\hline Inverse Mills Ratio & $?$ & $\begin{array}{c}0.167 \\
(3.09)^{* * *}\end{array}$ & \\
\hline No. of Observations & 1,172 & & \\
\hline Likelihood ratio $\chi^{2}$ & 391.35 & & \\
\hline Maximum Likelihood $\mathbf{R}^{2}$ & 0.684 & & \\
\hline
\end{tabular}

Notes to table 6: This table presents the results of two Probit models. Marginal effects are computed as: $\beta^{*}$ $\pi\left(X *\left[1-\pi(X]\right.\right.$, where $\pi(X)=e^{\beta^{\prime} X} /\left(1+e^{\beta^{\prime} X}\right)$ and $\beta^{\prime} X$ is evaluated at the mean values of $X$. For every observation we add discretionary accruals and the overall real earnings management proxy $\left(R \_M\right.$ Proxy) to obtain an overall measure of earnings management, TOTAL_EM. For Panel A, the dependent variable takes the value of 1 if the overall earnings management score is above the sample median earnings management score. If TOTAL_EM is lower than the median, the dependent variable for this observation takes the value of 0 . For Panel B, the dependent variable takes the value of $1 R_{-} M$ Proxy is higher than the sample median $R_{-} M$ Proxy. HAB_BEAT SHARES is the weighted average number of common shares outstanding at the beginning of the year, prior to the SEO; ANALYST is the number of analysts following the firm. BONUS is the average bonus compensation as a proportion of total compensation received by the CEO and the CFO of a firm; OPTION represents the Black-Scholes value of option compensation as a proportion of total compensation received by the CEO and the CFO of a firm; ROA is return on assets and is defined as income before extraordinary items divided by beginning of period total assets; MKT_CAP is market value of equity and is calculated as the closing price at fiscal year-end times the number of shares outstanding at fiscal year-end;

B_M is the Book-to-Market ratio, where the book value of common equity s divided by market value of equity; 
LEVERAGE is the sum of short term and long term debt divided by average total assets; $\triangle G D P$ is the seasonal annual change in GDP; $B I G 8$ is a dummy variable that equals 1 if the firm's auditor belongs to the Big 8 auditors and 0 otherwise; AUDIT TENURE is the log of the number of years the auditor has been with the firm; LITIGATION is a dummy variable equal to one if a firm's SIC code is 2833-2836, 87318734, 7371-7379, 3570-3577, 3600-3674 and zero otherwise; NOA is net operating assets which is calculated as the sum of shareholders' equity less cash and marketable securities and plus total debt at the beginning of the year, deflated by total sales for the previous year;

SOX is a dummy variable taking the value of one if the observation is after 2003 